\title{
MATURATION AND DESTRUCTION OF TRANSFUSED HUMAN RETICULOCYTES. EVALUATION OF RETICULOCYTE EXPERIMENTS FOR THE MEASUREMENT OF HEMOGLOBIN METABOLISM
}

\author{
BY LAWRENCE E. YOUNG AND JOHN S. LAWRENCE \\ (From the Department of Medicine, The University of Rochester School of Medicine and Dentistry, \\ and the Medical Clinic of the Strong Memorial Hospital, Rochester, New York)
}

(Received for publication December 29, 1944)

\begin{abstract}
A case of atypical hemolytic anemia, recently investigated in the Strong Memorial Hospital, furnished an unusual opportunity for determination of the in vivo maturation time and the fate of tranfused human reticulocytes. The results of this study aided in evaluating the usefulness of reticulocyte experiments in quantitative measurements of hemoglobin metabolism.
\end{abstract}

\section{PREVIOUS QUANTITATIVE ESTIMATES OF THE RATE OF PRODUCTION AND DESTRUCTION OF ERYTHROCYTES}

\section{Pigment determinations}

In normal animals, there is a fine balance between red cell formation and red cell destruction. Each day as the oldest cells are broken down, their place is taken by new cells which are constantly being released from the bone marrow. Therefore, it ought to be possible to estimate the pace of erythropoiesis by determining the rate of destruction of erythrocytes. This has been admirably accomplished in bile fistula dogs by measurements of the discarded pigment radicles ${ }^{1}$ which are excreted quantitatively in the bile $(1,2)$. The average life of red cells in the dog, estimated in this way (1), is approximately 124 days, which means that less than 1 per cent of the erythrocytes are destroyed and replaced daily.

\section{Transfusion studies}

This figure corresponds very well with estimates of the longevity of human red cells as determined by transfusion experiments, in which cells of one type are given to recipients of another (but compatible) type. Earlier transfusion studies, carried out with the original Ashby technique ( 3 to 5 ), yielded estimates ranging from 30 to

1 The destruction of 1 gram of hemoglobin is followed by the excretion of approximately $35 \mathrm{mgm}$. of bilirubin.
113 days. However, more recent investigations (6 to 12), employing improved technique and more carefully selected recipients, have resulted in agreement that the youngest of the transfused cells survive for periods of 100 to 140 days, provided the recipient's "hemolytic mechanism" is not abnormal (12).

\section{Reticulocyte experiments}

Attempts to measure the daily rate of red cell regeneration and the longevity of erythrocytes have also been made by attacking the problem at the opposite end of the erythroid series; i.e., by following the appearance and maturation of the youngest non-nucleated red cells, the reticulocytes, instead of observing the breakdown of the oldest cells as is done in the pigment and transfusion experiments. On the basis of observations of reticulocytes in rabbits, the average life of red cells has been placed at 8 days $(13,14)$, at 15 days (15), and at $42 \cdot$ days (16). Others (17) have found that most of the reticulocytes from human cases of anemia become mature within 48 hours. However, these authors estimate that normal human reticulocytes mature within 24 hours and that their life span is 125 days. Baar and Lloyd (18) studied the in vitro maturation time of reticulocytes from human cases of hemolytic anemia and from guinea pigs and rabbits with phenylhydrazine anemia. These authors estimate that the average maturation time of reticulocytes is 7 hours but add that it may be longer in cases with reticulocytosis. They (18) utilize the equations of Heilmeyer and Westhäuser (17) and make the following calculations which are based on the assumptions that all red cells enter the circulation from the bone marrow as reticulocytes, that they are not destroyed until they become mature, and that there are approximately 
0.7 per cent reticulated cells in the peripheral blood of normal human beings:

(1) Percentage of total red cells destroyed and replaced in 24 hours $=(0.7 \times 24) / 7=2.4$ per cent.

(2) Life span of red cells $=100 / 2.4=42$ days.

These investigators also contend that the above formulae can be applied to the calculation of the average life span of the red cells of any individual, regardless of whether the cells die of senescence or are destroyed indiscriminately without respect to age. An active case of acholuric jaundice is cited as one of a number of examples. This patient had a reticulocyte count of 14 per cent, and the life span of his cells is therefore estimated at 2 to 3 days and the "turnover" of the total red cell mass at nearly 50 per cent per day (19).

At the time the observations of Baar and Lloyd appeared, a very unusual case of atypical hemolytic anemia was being investigated in the hematological laboratories of the Strong Memorial Hospital. Month after month, the percentage of reticulated cells in this patient's circulation remained between 45 and 73 per cent. The formulae of Baar and Lloyd were applied to this case and, to be conservative, a reticulocyte maturation time of 14 hours-twice the average reported by these authors-was assumed. It was then calculated that this patient was destroying and replacing 77 to 120 per cent of her total red cell mass daily, and that the life span of the erythrocytes was only 20 to 30 hours! These figures seemed totally unreasonable. They were even more unacceptable when it was found that the patient's daily output of urobilinogen in the feces was approximately 600 mgm., ${ }^{2}$ which is only 3 to 10 times the amount excreted by normal persons and is a modest figure for an active case of hemolytic anemia (20).

\section{Disputed maturation time of reticulocytes}

Equally disturbing were the conflicting reports of Pepper (21), Heath and Daland (22), Minot and co-workers (23 to 25), and Riddle (26) on the one hand, and Mermod and Dock (27) on the other. Pepper found that reticulocytes could be

2 Some difficulty was encountered in the collection of feces from this patient, but this difficulty was not sufficiently great to alter the interpretation of the above results. demonstrated in rabbit or human blood as long as 48 hours after the beginning of incubation at $37^{\circ} \mathrm{C}$. Heath and Daland incubated sterile defibrinated blood from rabbits with phenylhydrazine anemia and from human patients with pernicious anemia at the height of their reticulocyte responses; the human blood was also placed in the pleural cavity of rabbits. When the percentages of reticulated cells were plotted as ordinates and time as abscissa, the results took the form of exponential curves indicating that reticulocytes matured over a period of 4 to 5 days. The curves were the same regardless of the source of the blood and were similar to those later obtained by Heilmeyer and Westhäuser (17).

The work of Minot's group indicates that, in the response to specific treatment of pernicious anemia, the reticulocytes mature within 5 to 10 days and that the magnitude of the reticulocyte response depends largely upon the severity of the anemia. Riddle found that during response to treatment of pernicious anemia the non-reticulated red cells increased in a manner similar to the total red cell count, but lagged behind by at least 2 days. The maturation time of the reticulocytes is therefore estimated at 2 to 4 days.

Mermod and Dock, however, could demonstrate no evidence of maturation of reticulocytes in defibrinated rat and human blood incubated at $37^{\circ}$ C. for periods of 24 to 72 hours. Furthermore, these authors state that maturation of reticulocytes in the circulating blood is not proved and seems not to occur on any significant scale. Mermod and Dock also found that reticulocytes are readily destroyed in vivo and in vitro by various substances, and they suggest that recovery from anemia occurs in spite of premature delivery of fragile, short-lived reticulocytes, not because of it.

Consideration of these conflicting observations and opinions furnished the impetus for carrying out the experiments described in this paper. The purposes of this study were:

1. To measure the in vivo maturation time of the reticulocytes of the patient with atypical hemolytic anemia when transfused in large quantity to a small child with aplastic anemia;

2. To compare with the in vivo results, in vitro maturation time of reticulocytes from the same source; 
3. To determine, if possible, the fate of the transfused reticulocytes;

4. To evaluate the usefulness of reticulocyte experiments in the quantitative study of the formation and destruction of red blood cells.

\section{METHODS}

\section{Counting of reticulocytes}

Two methods were used for the enumeration of reticulocytes.

1. "Dry" method. A filtered alcoholic solution of brilliant cresyl blue dye $(0.5 \mathrm{gram}$ dye per $100 \mathrm{ml}$. of absolute ethyl alcohol) was poured over one side of a clean glass slide which was then tilted on end until dry. A small drop of blood (either capillary or oxalated venous blood) was placed in the center of a glass cover slip which was immediately inverted on the slide. Spreading of the drop between the cover slip and the slide was promoted by very light pressure. The cover glass was sealed at once with vaseline and the preparation incubated at $37^{\circ} \mathrm{C}$. for 10 to 20 minutes before being examined. ${ }^{3}$

2. "Wet" method. Blood was drawn into the stem of a Thoma white cell counting pipette to the 0.5 mark and diluted to the 11 mark with a filtered saline solution of brilliant cresyl blue $(0.2$ gram dye per $100 \mathrm{ml}$. of 0.6 per cent solution of sodium chloride in distilled water). After' being shaken for 30 seconds, the pipette was incubated 10 to 20 minutes at $37^{\circ} \mathrm{C}$. The pipette was then shaken again for 30 seconds, several drops were discarded into a piece of gauze, and a small drop of the stained and diluted blood placed on a clean glass slide. A cover slip was then placed over the drop which spread quickly without any pressure, and the preparation was ready for examination. Sealing with vaseline was found unnecessary. This method offered 3 advantages: (1) intimate mixture of dye and cells in the wet state, (2) sufficiently thin preparation, and (3) absence of rouleaux.

Cells stained by either method were viewed slowly through a small hole in a piece of cardboard inserted in the ocular of the microscope. At stated intervals, 1 or 2 counts of 1000 cells each were made by each of the 2 methods; i.e., 2000 to 4000 cells were counted. There was no significant difference in the counts made by the 2 methods.

\section{Use of Simmel's solution}

In vitro studies of the maturation of reticulocytes were carried out by a modification of the method of Baar and Lloyd (18) which consisted of incubating blood in sterile, citrated Simmel's (28) solution ( $\mathrm{NaCl} 8.2, \mathrm{KCl} 0.2$, $\mathrm{MgCl}_{2} 0.2, \mathrm{CaCl}_{2} 0.2, \mathrm{NaH}_{2} \mathrm{PO}_{4} 0.1, \mathrm{NaHCO}_{3} 0.05$ grams per liter of distilled water to which one-fifth part of 3.8

8 Preliminary tests failed to show conclusively that incubation was necessary; nevertheless, this was done because there was no opportunity for further investigation of the necessity of this procedure. per cent sodium citrate solution was added). One ml. of Simmel's solution was placed in each of a number of small, sterile, corked tubes and 4 drops of blood were added to each tube. Whenever counts were made from one of these the remaining tubes were shaken and replaced in the incubator. Staining with brilliant cresyl blue was done by the same methods used for undiluted blood, with the exception that the blood diluted with Simmel's solution was drawn to approximately the middle of the bulb of the white cell pipette instead of the 0.5 mark on the stem. At each interval, 2 samples were taken from one of the tubes and staining was carried out by both the dry and the wet methods.

\section{Differential agglutination}

The survival of transfused erythrocytes was followed by use of the Ashby technique (3) as modified by Dacie and Mollison (10). The only deviation from this method was that of preparing an initial 1 in 101 suspension of the recipient's blood instead of a 1 in 51 suspension. Each mixture of serum and cells was prepared in duplicate and a separate count ( 5 small squares on the improved Neubauer ruling) of the unagglutinated cells in each tube was made by each of 2 persons. The final count recorded was therefore the average of 4 separate counts of each mixture of serum and cells.4 Total red blood cell counts were likewise made in duplicate by 2 persons and the average of the 4 counts recorded.

The extremely potent $B$ serum employed was prepared by vaccination of $a B$ donor with $A$ and $B$ specific substances and titrated with $A_{1}, A_{2}, A_{1} B, A_{2} B$, and $A_{8} B$ cells as described elsewhere (29). When this serum, which was used undiluted, was mixed with a pretransfusion sample of the recipient's $A_{2}$ cells, there were approximately 15,000 unagglutinated cells per c.mm. The anti-M serum was supplied by Dr. A. S. Wiener and diluted $1: 3$ with saline before being mixed with cell suspensions. When this serum was added to a pretransfusion sample of the recipient's blood, there were 10,000 unagglutinated cells per c.mm.

Total red cell counts, differential agglutination studies, hemoglobin (photoelectric), and hematocrit (Wintrobe) determinations were made with venous blood drawn without stasis into a mixture of potassium and ammonium oxalate $(30)$ at $37^{\circ} \mathrm{C}$. Counts from these tubes were likewise made at frequent intervals by the methods described, and in this way the in vitro and in vivo maturations of reticulocytes from the same source were compared.

The average figures for percentage of reticulocytes in the recipient's blood are plotted as ordinate and time as

4 Control tubes containing 1:201 dilutions of blood in saline were always prepared along with the mixtures of cell suspension and serum. Counts made from these "saline" tubes were nearly always higher than those made from the Thoma standardized diluting pipette. Therefore, the count of unagglutinated cells was always corrected by multiplying this figure by the count from the Thoma pipette and dividing the product by the count from the control tube of saline. 


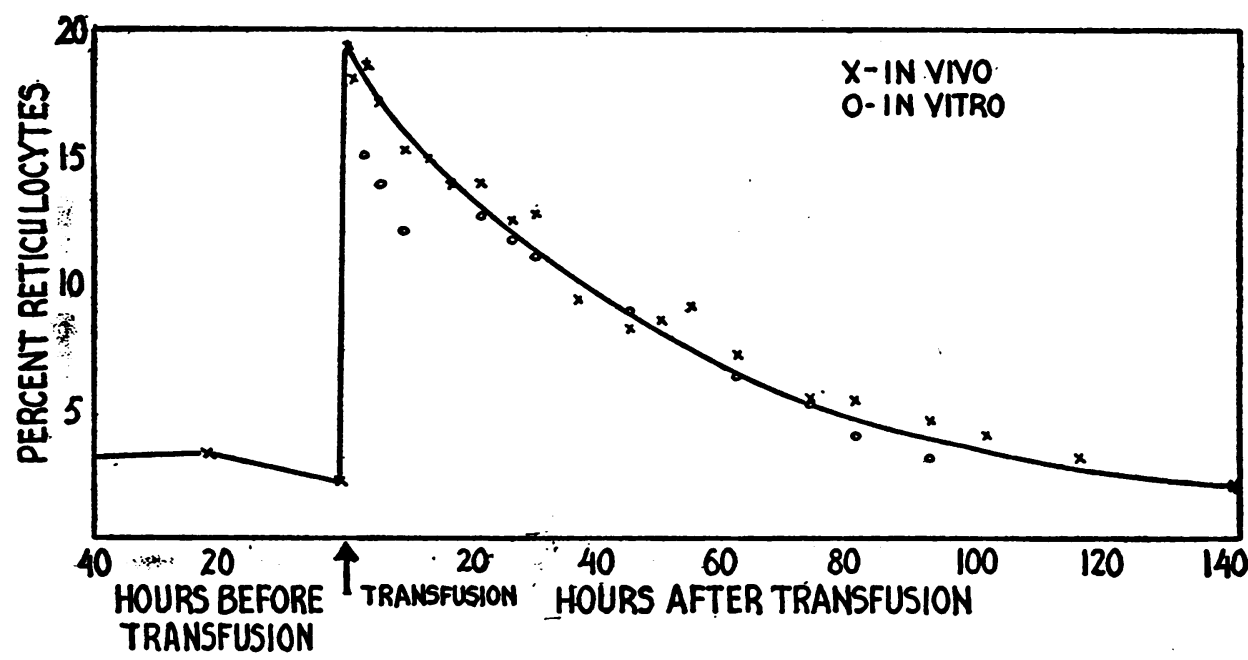

Fig. 1. Percentage of Reticulocytes in Circulation of Child with Aplastic Anemia Before and After Transfusion of Red Cells from Adult Patient with Hemolytic ANEmia

The in vivo maturation of reticulocytes is compared with the in vitro maturation of cells from the same source when incubated in Simmel's solution.

abscissa in Figure 1. An exponential curve is readily drawn through these points, and it is apparent that the in vivo and in vitro results are almost identical except for appreciably lower in vitro counts during the first few hours of the experiment. Hemolysis of the cells in Simmel's solution was not detectable until after the fourth day. The last reliable in vitro counts were made 93 hours after the beginning of incubation of the tubes. During the period of observation, there was not only a gradual decrease in the number of reticulocytes but also a diminution in the amount of vitally staining substance present in the remaining reticulocytes. Moreover, in the incubated cells, there was some degree of replacement of filaments by granules, similar to those described in the in vitro studies of others $(22,11,18)$.

In vivo destruction of transfused reticulocytes following their maturation

The blood group of the patient with atypical hemolytic anemia was OMNRh +; that of the child with aplastic anemia was $A_{2} M N R h+$. When $B$ serum was added to suspensions of the child's red cells after transfusion, the $A$ cells were agglutinated, while the donated $O$ cells were left unagglutinated and could be counted with accuracy by the method described. In this way, it was possible to determine quantitatively the rate at which the transfused cells, most of which were reticulocytes, disappeared from the recipient's' circulation.

Calculation of the values for total donated cells, donated reticulocytes, and donated mature (non-reticulated) cells at each interval can be summarized as follows:

I. Total number donated cells = number cells not agglutinated by $B$ serum minus 15,000 .
II. Number donated reticulocytes = total number donated cells $\mathrm{X}$ (total percentage reticulocytes minus 2.5 per cent).

III. Number donated mature cells = total number donated cells minus number donated reticulocytes.

In formula I, 15,000 cells per c.mm. are subtracted because this was the count of unagglutinated cells prior to transfusion. Formula II is based on the assumption that approximately 2.5 per cent of the reticulocytes present at any given time were the recipient's own cells. All donated red cells are arbitrarily divided into reticulated (immature) and non-reticulated (mature) forms in formula III.

It can be seen in Figure 2 that the total number of donated cells remained nearly constant during the first 2 days after transfusion, and that during this period, there was a marked decrease in reticulocytes and a corresponding increase in mature cells. In the following period of 4 days, there was a rapid fall in the total number of donated cells, and the remaining reticulocytes became mature. The few donated cells remaining at the end of 6 days were free of reticulum and were eliminated during the seventh and eighth days, as demonstrated by further differential agglutination studies.

\section{The comparatively slow destruction of transfused normal cells}

Because the length of time the child could remain in the hospital was limited, it was necessary to give her 250 ml. of normal red cells on the fifth and again on the sixth day after the transfusion of reticulocytes. It is clear from Figure 1, however, that the percentage of reticulocytes in the recipient's circulation had returned nearly to the 


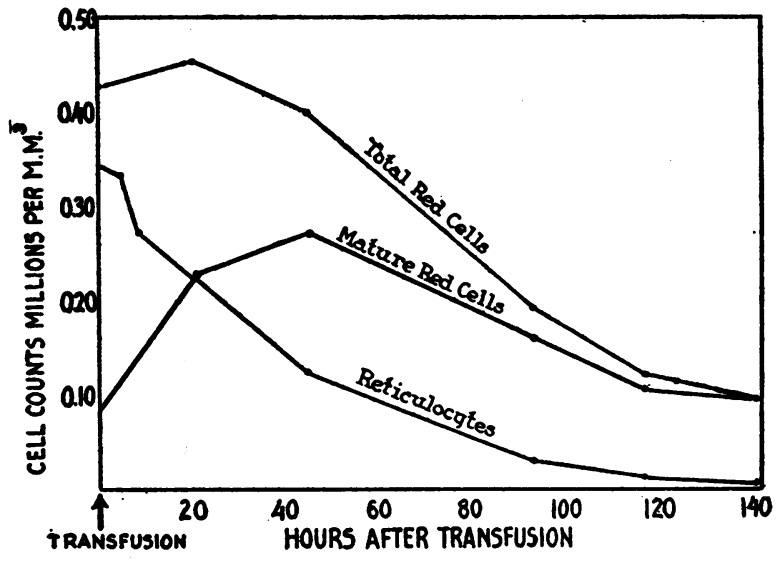

Fig. 2. Fate of Red Cells from Adult Patient with Hemolytic Anemia After Transfusion to Chind with Aplastic Anemia

The few mature cells remaining at 140 hours were destroyed during the next 2 days (Table I). The graph was not extended to show this destruction because large errors are involved in cell counts below 100,000.

original level before the transfusions of normal cells were given. The blood group of the normal cells was ONRh +. It was therefore possible to follow the sur- vival of these cells by the use of anti-M serum which agglutinated the cells of the recipient (type MN). Calculation of the distribution of cells in the child's circulation was then carried out as follows:

I. Number $\mathrm{ON}$ cells from normal donors = number of cells not agglutinated by anti-M serum minus 10,000 .

II. Number of OMN cells from patient with hemolytic anemia $=$ number of cells not agglutinated by $B$ serum minus 15,0000 minus number of $\mathrm{ON}$ cells.

The calculated number of OMN cells was less than 20,000 per c.mm. on the seventh day after the transfusion of these cells, and subsequent examinations during the next 37 days confirmed the fact that all of these cells had been eliminated from the child's circulation. During this period, it was shown (Table I) that the count of normal ON cells, which was $2,800,000$ on the first day after the last transfusion, had decreased to $2,140,000$ in 17 days and to $1,300,000$ in 38 days. It was necessary to terminate the study on the thirty-eighth day, and therefore the length of time required for the complete destruction of the normal ON cells cannot be given. However, it appears that, although these cells were destroyed more slowly than the OMN cells, the rate of their elimination was possibly more rapid than that of normal cells in the circulation of recipients with normal hemolytic mecha-

TABLE I

Detailed hematologic observations on blood of child with aplastic anemia before and after transfusion of reticulated OMN cells and normal $O N$ cells

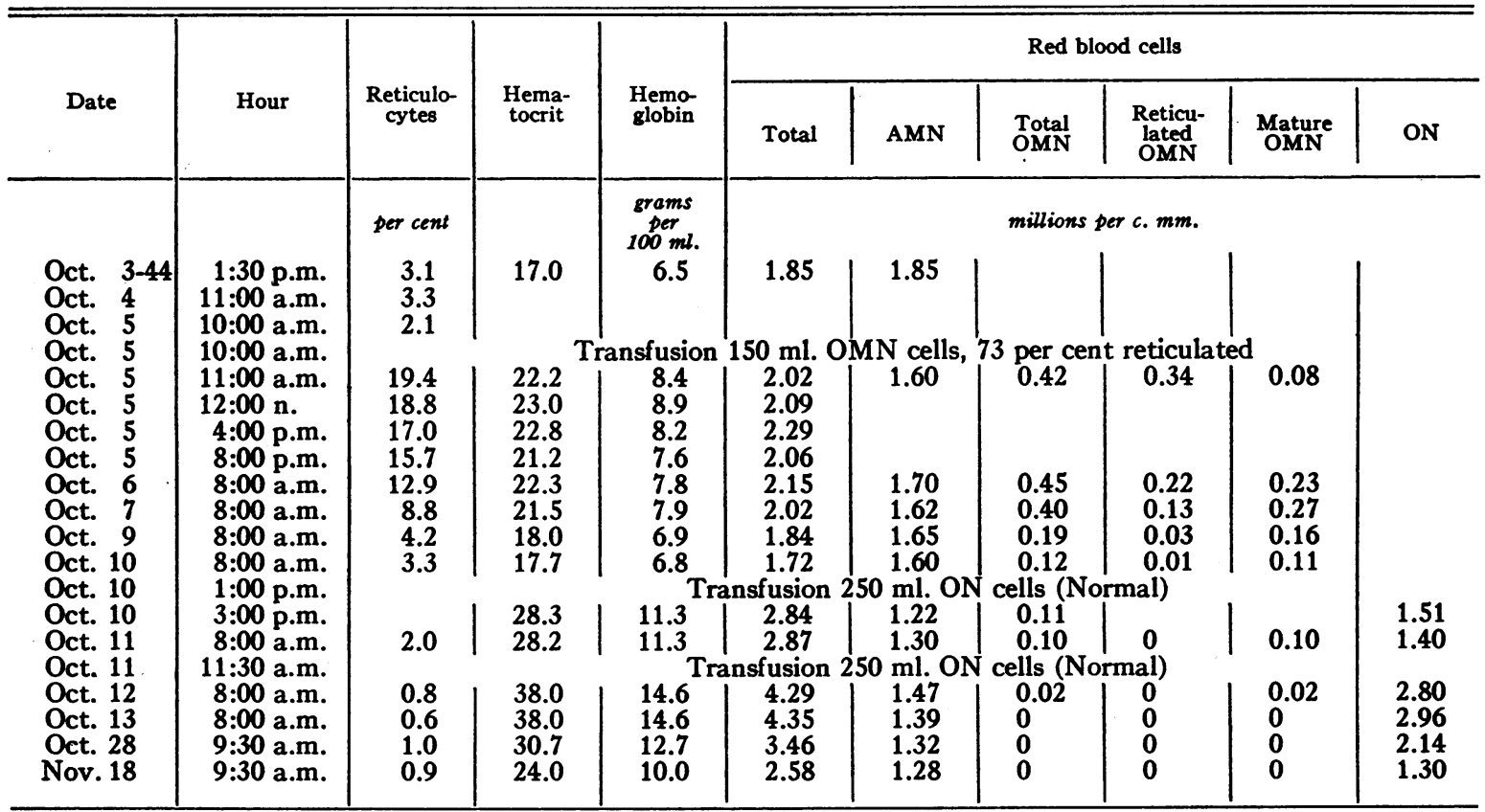

Figures for percentage reticulocytes after transfusion were obtained from curve shown in Figure 1 . The relatively small increase in total red cell count produced by the transfusion of OMN cells was due to the fact that the mean corpuscular volume (MCV) of these cells was $138 \mathrm{c} . \mu$. These cells were loosely packed when the $150 \mathrm{ml}$. volume was measured. The MCV of the ON cells was presumably normal. 
nisms (6 to 12). It is therefore possible that there was a small hemolytic element in the anemia of the child whose disease had been labelled "aplastic anemia." Unfortunately, quantitative determination of fecal urobilinogen could not be obtained in order to settle this issue.

\section{A second determination of the maturation time of reticu-} locytes in vitro

On October 17, 1944, $20 \mathrm{ml}$. of blood were drawn from M. G., the patient with atypical hemolytic anemia. A 10 $\mathrm{ml}$. portion was defibrinated by gentle shaking with a small number of glass beads in an Erlenmeyer flask, after which, $1 \mathrm{ml}$. of the defibrinated blood was placed in each of 8 small, sterile, tightly-stoppered tubes. No grossly detectable hemolysis was produced by this procedure. The remainder of the whole blood was distributed among tubes of Simmel's solution by the method previously described. All but one of the tubes of each type were incubated at $37^{\circ} \mathrm{C}$.

At intervals of 7 to 26 hours during the next 6 days, one tube of defibrinated blood and one tube of blood diluted with Simmel's solution were removed from the incubator for examination, and the remaining tubes were shaken and replaced in the incubator. Both "wet" and "dry" preparations were made with brilliant cresyl blue and the reticulocytes counted as before. During the first 48 hours of incubation, the percentage of reticulated cells in the defibrinated blood was not significantly different from that of the cells suspended in Simmel's solution. The average of the counts from both tubes at each interval is therefore recorded in Figure 3. After 48 hours, however, there was considerable hemolysis of the defibrinated blood and counts made from the defibrinated samples after that time were considered unreliable. The remainder of the graph shown in Figure 3 is therefore based only upon the counts of the reticulated cells in Simmel's solution in which there was but slight hemolysis on the fifth and sixth days. In spite of the fact that the reticulocytes were enumerated at relatively long intervals and that the defibrinated blood proved unsatisfactory, this rather crude in vitro experiment served to confirm the previously obtained results.

At the time blood was drawn for this experiment, the percentage of reticulocytes in the patient's blood had decreased to 29.6 , presumably as a result of the transfusion given 12 days previously. However, the exponential curve showing the maturation of reticulocytes during a period of 6 days is very similar to that obtained as a result of the earlier combined in vivo and in vitro study.

\section{DISCUSSION}

In the case presented in this paper, the child's reticulocyte count was raised by nearly 17 per cent as a result of transfusion, and the gradual decline in the percentage of reticulated cells took place over a period of approximately 140 hours, or roughly 5 to 6 days. Baar and Lloyd (18), who

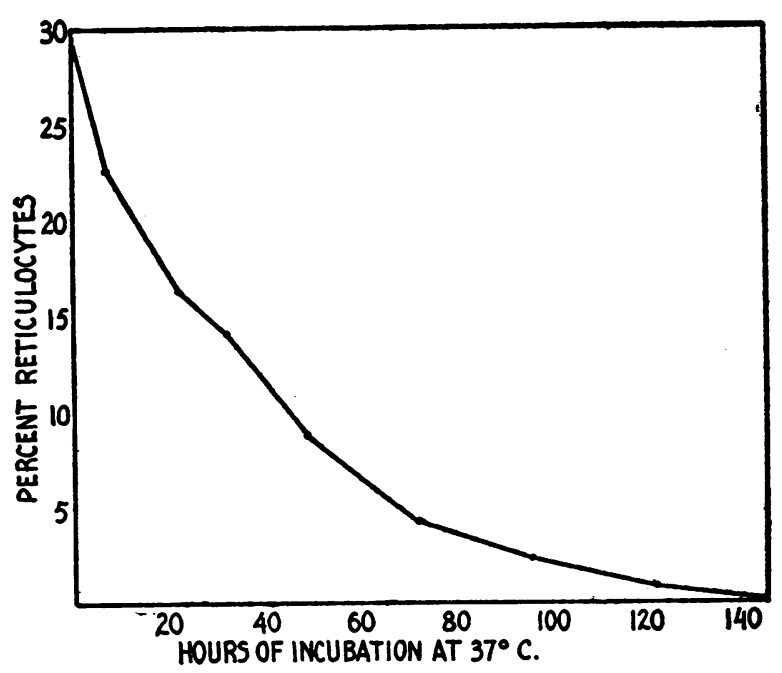

Fig. 3. In Vitro Maturation of Reticulocytes froy Patient with Hemolytic ANemiad

performed the only previous experiment of this type, produced an increase of 5.4 per cent in the reticulocyte count of an infant by transfusing blood from a patient with acholuric jaundice. The in vitro maturation time of reticulocytes from this patient is recorded by these authors as 6 hours, which is approximately the time required for the in vivo maturation of the transfused reticulocytes in the circulation of the infant.

There are 3 possible explanations for the marked discrepancy in these 2 estimates of maturation time.

1. The experimental error in the counting of reticulocytes is known to be large; this is particularly true when dealing with numbers as small as 5.4 per cent. Heath and Daland (22) admit that no conclusions can be drawn from their own transfusion experiments in which the reticulocyte counts of rabbits were raised by only 3 to 6 per cent.

2. Baar and Lloyd (18) determine maturation time by extrapolation of the initial steep slope of the maturation curve to the ordinate zero. It is difficult to follow the reasons given by these authors for using this procedure which, if applied to the reticulated cells of Figures 1 and 3 , might yield estimates as low as 20 to 40 hours. It seems more reasonable to consider the interval between the beginning of the experiment and the hour at which the base-line is first reached, as the maturation time of the youngest reticulocytes. 
3. The length of time required for a reticulated cell to lose its vitally staining substance may vary somewhat depending upon its source. Baar and Lloyd suggest that this period may be relatively long in cases with reticulocytosis and short in cases of pernicious anemia. Heilmeyer and Westhäuser (17) found that maturation curves vary somewhat depending upon the source of the blood, but in all cases, the general trend is the same. Riddle (26) believes it likely that in normal and less anemic individuals, the reticulocytes are retained longer in the marrow and developed nearer to maturity before release, and may therefore require less time in the circulation to lose their reticulum.

Comparison of in vivo and in vitro studies of the maturation of reticulocytes

Among those who have compared the in vivo and in vitro maturation of reticulocytes $(18,22)$, there is general agreement that the results are essentially the same by either method. Not only are similar estimates of maturation time obtained, but the same sort of exponential maturation curve can be plotted with figures obtained in either way. This can also be said of the data presented in this paper. It should be emphasized, however, that the in vivo observations recorded here were obtained by utilizing a case that was far more advantageous than any previously investigated. The correlation of the in vivo and in vitro results in this case is therefore of special interest.

\section{Fate of transfused reticulocytes}

It has already been pointed out that during the first 2 days after the transfusion, the total count of donated cells fell but little, while there was a marked decrease in percentage of reticulocytes (Figure 2). It can therefore be concluded that during this interval many of the reticulated cells became mature. During the first 2 days, there was a preponderance of maturation and a minimum of red cell destruction, but during the next 4 days, after most of the cells had become mature, the reverse was true. These findings are sufficient to disprove the contention of Mermod and Dock (27) that reticulocytes do not mature in the circulating blood. These investigators argue that the reticulum merely becomes more difficult to stain and that these cells do not really mature with in- cubation. They attribute the results of Heath and Daland (22) to the use of "dry" staining technique. However, in the present study both wet and dry techniques were used with nearly identical results.

The observations shown in Figure 2 support the opinion of Baar and Lloyd (18) that reticulocytes are not destroyed until they become mature and they are also in keeping with Cruz' observation that reticulocytes are not destroyed by acetylphenylhydrazine (32). At present, it is possible only to speculate on the explanation for this peculiar immunity to destruction.

It must also be admitted that under certain conditions reticulocytes may be destroyed as readily, or perhaps more readily, than mature cells. Rhoads et al. (33) produced hemolytic anemia with indol in dogs fed deficient diets and attributed the lack of reticulocytosis to rapid destruction of immature cells. Dock (34) found doses of saponin which on injection into rabbits destroyed circulating reticulocytes with negligible effect on mature cells, and Dock and Mermod (35) demonstrated a reticulocyte lysin in the serum of active cases of pernicious anemia. It has been suggested that such a lysin is responsible for increased pigment excretion and lack of reticulocytosis in this disease before specific therapy is given.

\section{Defectiveness of reticulocytes}

The red cells of the patient with atypical hemolytic anemia are destroyed rapidly, not only in her own body but after transfusion to a child whose circulation retains normal erythrocytes for much longer periods. These facts indicate that the cells of M. G. ${ }^{5}$ are abnormal, but there is uncertainty as to whether they are structurally defective in the same sense as spherocytes and sickle cells, or defective merely because they happen to be released from the marrow in the reticulated form. It is reasonable to suspect that in certain anemias, the marrow is working under difficulties and therefore turns out cells with defective stroma, as

5 Normal ON cells were transfused to patient M. G. on 2 separate occasions. The donated erythrocytes survived 114 days after the first transfusion, and 790,000 donated cells per c.mm. were counted 39 days after the second transfusion (31). 
suggested by Whipple (36). There is no proof, however, that such defectiveness is limited to cells which leave the marrow in the reticulated stage. There is also no evidence that under normal conditions cells entering the circulation in this earlier stage of development have any shorter life expectancy than those leaving the marrow without vitally staining substance.

It is virtually impossible to study the behavior of reticulocytes from normal human beings and lower animals because they are present in the blood in very small numbers. All published observations on reticulocytes, including those described in this report, have been made with blood drawn from abnormal mammals or normal mammals subjected to abnormal conditions. Great caution must therefore be taken in applying these results to the behavior of the normal erythron.

\section{Use of reticulocyte experiments in the study of hemoglobin metabolism}

It is of interest to compute the life span of the red cells of patient M. G. by using the formulae of Heilmeyer and Westhäuser (17) and Baar and Lloyd (18). If the reticulocyte count is 73 per cent $^{\circ}$ and the maturation time 140 hours, then the daily rate of regeneration of red cells is $(73 \times 24) / 140=12.5$ per cent and the average life span of the cells is $100 / 12.5=8$ days.

This figure coincides with the 8-day period of survival actually observed after transfusion of the cells into the child. This correlation indicates that in the case of M. G. nearly all of the cells were leaving the marrow in the reticulated stage and were not destroyed until they had matured. It will be recalled that these were the assumptions on which the above formulae were based.

Prior to the transfusion experiment the body weight of patient M. G. was $67 \mathrm{kgm}$., estimated blood volume approximately $6000 \mathrm{ml}$., hemoglobin 9.5 grams per $100 \mathrm{ml}$., and total circulating hemoglobin $\mathbf{5 7 0}$ grams. If the entire red cell mass was being broken down and replaced every 8 days, then the calculated rate of hemoglobin "turnover" is 71 grams per day. This figure is approxi-

- The percentage of M. G.'s cells that are reticulated is 80 , if calculated from the data shown graphically in Figure 2. However, this figure is obviously less accurate than the direct count of 73 per cent made just before the blood was transfused. mately 10 times that ( 7.2 grams per day) calculated for a normal person of the same body weight but with 15 grams of hemoglobin per $100 \mathrm{ml}$. of blood and with a red cell longevity of 125 days.

If $35 \mathrm{mgm}$. of bilirubin are formed from the breakdown of each gram of hemoglobin, the calculated rate of bilirubin excretion from the common bile duct of patient M. G. is $2485 \mathrm{mgm}$. per day, as compared with $252 \mathrm{mgm}$. per day in the normal individual of the same body weight. The quantitative elimination of bilirubin in bile fistula dogs has been amply demonstrated $(1,2)$, but the ratio between output of bilirubin in the bile and excretion of urobilinogen in the feces has never been accurately determined. No doubt this ratio is subject to considerabale variation under normal as well as abnormal conditions. According to Watson (20), the fecal urobilinogen excretion of normal adults varies from 40 to $280 \mathrm{mgm}$. per day (usually 100 to $200 \mathrm{mgm}$.), while in cases of hemolytic anemia, values ranging from 300 to $4000 \mathrm{mgm}$. per day (usually 600 to $2000 \mathrm{mgm}$.) are recorded.

In June 1944, when the reticulocyte count was 62 per cent, urobilinogen was excreted in the feces of M. G. at the rate of $600 \mathrm{mgm}$. per day. However, the fecal collections were rather unsatisfactory and this figure is probably much below the true value. The need for accurate determinations of fecal urobilinogen excretion in conjunction with transfusion experiments of the type reported in this paper is apparent.

If the maturation time of all reticulocytes is approximately 140 hours, as previously suggested, and the normal average reticulocyte count in human beings is 0.7 per cent, then the normal average daily rate of red cell regeneration is $(0.7 \times 24) / 140=0.12$ per cent and the average life span of the cells is $100 / 0.12=833$ days.

This estimate is 7 to 8 times greater than those based on pigment studies and transfusion experiments, the results of which are not acceptable to Baar and Lloyd for reasons that are difficult to follow $(19,37)$. These authors, however, place the average life span of normal erythrocytes at 42 days which is nearly 20 times lower than the figure of 833 days computed with their formulae.

There are 3 possible explanations for the failure of these calculations to provide a reasonable estimate of the longevity of red cells : 
1. Determinations of the maturation time of reticulocytes may be erroneous. The 140-hour figure has already been defended and nothing more can be added here.

2. Reticulocytes may be destroyed before they become mature. However, it is unlikely that this takes place in normal individuals and it is reasonably certain that this did not occur in the case which formed the basis for this report.

3. By far the most important reason for the incongruity of the figures calculated according to the equations of Baar and Lloyd, and for the failure of reticulocyte experiments to measure the tempo of hemoglobin metabolism, is that not all red cells enter the circulation in the reticulated form.

This belief is supported by the classic observations of Minot's group who conclude that only in the more anemic patients with pernicious anemia can the initial increase in total red count be attributed entirely to the production of reticulocytes following specific therapy. These investigators add that since the total red cell count continues to rise after the percentage of reticulocytes has reached a peak and returned again to a normal level, it must be concluded that enough time has elapsed so that most of the erythrocytes are mature when released from the marrow. Moreover, in less anemic patients, even the initial increase in total red cells is due largely to the release of erythrocytes which are already mature when they enter the circulation.

Additional evidence is furnished by the observations of Rioch and Robscheit-Robbins (38) who found no correlation between reticulocyte formation and output of hemoglobin in standard anemic dogs.

In view of these facts, it is likely that, under normal conditions, only a small percentage of the red cells delivered from the marrow contains detectable amounts of vitally staining substance. This is the chief reason for the distinctly limited usefulness of reticulocyte experiments in estimating the daily rate of red cell regeneration and the life span of erythrocytes.

\section{SUM MARY}

1. Approximately $150 \mathrm{ml}$. of red cells, 73 per cent of which were reticulated, were removed from a patient with atypical hemolytic anemia and transfused to a child with probable aplastic anemia. The number of reticulocytes in the child's circulation was thus raised by 17 per cent.

2. The transfused reticulocytes gradually matured over a period of about 140 hours. A similar maturation curve and estimate of maturation time were obtained by in vitro incubation of the same blood in Simmel's solution.

3. All of the transfused cells were destroyed in approximately 8 days, but it was demonstrated that the reticulocytes were not destroyed until they had become mature. It is emphasized that these cells were abnormal and that for this reason the results of this experiment must be applied with great caution to the behavior of the normal erythron.

4. It is concluded that reticulocyte experiments have only limited usefulness in estimating the daily rate of red cell regeneration and the life span of erythrocytes because:

a. The maturation time and fate of reticulocytes may vary, depending upon the conditions under which they are produced;

b. Under certain circumstances, reticulocytes may be destroyed before they become mature ;

c. Under normal conditions and in some phases of the response to anemia, most of the red cells probably enter the circulation in the non-reticulated form.

The authors are indebted to Miss Helen Zimmerman and Miss Leah Schwendler for technical assistance, and to Dr. William B. Hawkins for many helpful suggestions during the preparation of this report.

\section{BIBLIOGRAPHY}

1. Hawkins, W. B., and Whipple, G. H., The life cycle of the red blood cell in the dog. Am. J. Physiol., 1938, 122, 418.

2. Cruz, W. O., Hawkins, W. B., and Whipple, G. H., Acetylphenylhydrazine anemia. 2. Bile pigment elimination and new hemoglobin reconstruction in the bile fistula dog. Am. J. M. Sc., 1942, 203, 848.

3. Ashby, W., Determination of length of life of transfused blood corpuscles in man. J. Exper. Med., 1919, 29, 267.

4. Ashby, W., Study of transfused blood. 2. Blood destruction in pernicious anemia. J. Exper. Med., $1921,34,147$.

5. Wearn, J. T., Warren, S., and Ames, O., Length of life of transfused erythrocytes. Arch. Int. Med., 1922, $29,527$. 
6. Wiener, A. S., Longevity of the erythrocytes. J. A. M. A., 1934, 102, 1779.

7. Wiener, A. S., and Schaefer, G., Limitations in the use of preserved blood for transfusion. Med. Clin. North America, 1940, 24, 705.

8. Denstedt, O. F., Osborne, D. E., Stansfield, H., and Rochlin, I., The survival of preserved erythrocytes after transfusion. Canad. M. A. J., 1943, 48, 477.

9. Denstedt, O. F., Osborne, D. E., Stansfield, H., and Rochlin, I., The survival of preserved red cells after transfusion. Anesthesiology, 1944, 5, 237.

10. Dacie, J. V., and Mollison, P. L., Survival of normal erythrocytes after transfusion to patients with familial haemolytic anaemia. Lancet, 1943 1, 550.

11. Mollison, P. L., The survival of transfused erythrocytes in haemolytic disease of the newborn. Arch. Dis. Childhood, 1943, 18, 161.

12. Brown, G. M., Hayward, O. C., Powell, E. O., and Witts, L. J., The destruction of transfused erythrocytes in anaemia. J. Path. and Bact., 1944, 56, 81.

13. Eaton, P., and Damren, F. L., A method for determining the life duration of the erythrocyte. South. M. J., 1930, 23, 311.

14. Eaton, P., and Damren, F. L., The rate of red cell production after hemorrhage. South. M. J., 1930, 23, 395 .

15. Schulten, H., Uber den Verlauf der Blutregeneration nach Anämien. Folia Haemat., 1930, 42, 158.

16. Kurtz, P. L., An experimental index of erythropoietic function in rabbits. Am. J. Physiol., 1937, 119, 24.

17. Heilmeyer, L., and Westhäuser R., Reifungsstudien an überlebenden Reticulocyten in vitro and ihre Bedeutung für die Schätzung der täglichen Haemoglobin-produktion in vivo. Ztschr. f. klin. Med., 1932, 121, 361.

18. Baar, H. S., and Lloyd, T. W., Studies in the anemias of infancy and early childhood. Part XII. The regeneration rate of haemoglobin and the life span of erythrocytes in normal and pathological conditions. Arch. Dis. Childhood, 1943, 18, 1.

19. Baar, H. S., and Lloyd, T. W., Studies in the anemias of infancy and early childhood. Part XIV. The fate of transfused erythrocytes. Arch. Dis. Childhood, 1943, 18, 124.

20. Watson, C. J., The bile pigments. New England J. Med., 1942, 227, 665 and 705.

21. Pepper, O. H. P., Observations on vitally stainable reticulation and chromatic granules in erythrocytes preserved in vitro. Arch. Int. Med., 1922, 30, 801.

22. Heath, C. W., and Daland, G. A., The life of reticulocytes; experiments on their maturation. Arch. Int. Med., 1930, 46, 533.

23. Minot, G. R., Murphy, W. P., and Stetson, R. P., The response of the reticulocytes to liver therapy: particularly in pernicious anemia. Am. J. M. Sc., 1928, 175, 581.
24. Minot, G. R., Cohn, E. J., Murphy, W. P., and Lawson, $H$. A., Treatment of pernicious anemia with liver extract: effects upon the production of immature and mature red blood cells. Am. J. M. Sc., 1928, 175, 599.

25. Cohn, E. J., Minot, G. R., Alles, G. A., and Salter, W. T., The nature of the material in liver effective in pernicious anemia. II. J. Biol. Chem., 1928, 77, 325.

26. Riddle, M. C., Pernicious anemia. Blood regeneration during early remission. Arch. Int. Med., 1930, 46, 417.

27. Mermod, C., and Dock, W., Fragility and maturation of reticulocytes. Arch. Int. Med., 1935, 55, 52.

28. Simmel H., Die Prüfung der osmotischen Erythrocytenresistenz. Ergebn. Inn. Med. Kinderheilk., 1925, $27,507$.

29. Young, L. E., and Witebsky, E., Studies of the subgroups of blood groups $\mathrm{A}$ and $\mathrm{AB}$. II. The agglutinogen $\mathrm{A}_{3}$; its detection with potent $B$ serum and an investigation of its inheritance. J. Immunol., in press.

30. Heller, V. G., and Paul, H., Changes in cell volume produced by varying concentrations of different anticoagulants. J. Lab. and Clin. Med., 1934, 19, 777.

31. Young, L. E., and Lawrence, J. S., Atypical hemolytic anemia, with special reference to the use of transfusions in the study of hemolytic mechanisms. In preparation.

32. Cruz, W. O., Acetylphenylhydrazine anemia. 1. The mechanism of erythrocyte destruction and regeneration. Am. J. M. Sc., 1941, 202, 781.

33. Rhoads, C. P., Barker, W. H., and Miller, D. K., The increased susceptibility to hemolysis by indol in dogs fed deficient diets. J. Exper. Med., 1938, 67, 299.

34. Dock, W., The importance of hemolysis in the pathogenesis of macrocyctic anemia. Medical Papers Dedicated to Dr. Henry A. Christian. Waverly Press, Baltimore, 1936, page 545.

35. Dock, W., and Mermod, C., Hemolysins to which reticulocytes are especially vulnerable in the plasma of primary anemia. Proc. Soc. Exper. Biol. and Med., 1934, 32, 373.

36. Whipple, G. H., Pigment metabolism and regeneration of hemoglobin in the body. Arch. Int. Med., 1922, 29, 711.

37. Baar, H. S., Studies in the anemias of infancy and early childhood. Part XIII. Experiments on blood regeneration and their significance for the life span of erythrocytes. Arch. Dis. Childhood, $1943,18,65$.

38. Rioch, J., and Robscheit-Robbins, F. S., The response of reticulocytes to potent diets in severe experimental anemia due to hemorrhage. Am. J. M. Sc., 1932, 184, 304. 